
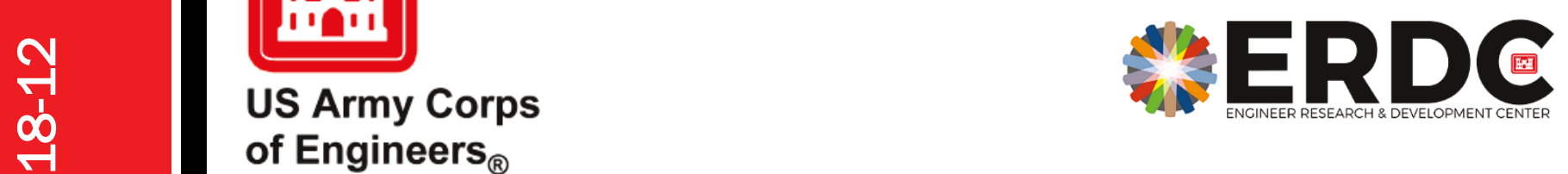

Engineer Research and

Development Center

Aquatic Plant Control Research Program (APCRP)

\title{
Abiotic Removal of Phosphate From Surface Water - Bench Scale to Meso-Scale
}

Carina M. Jung, Jed O. Eberly, G. Alon Blakeney,

October 2018 and Heather M. Knotek-Smith 
The U.S. Army Engineer Research and Development Center (ERDC) solves the nation's toughest engineering and environmental challenges. ERDC develops innovative solutions in civil and military engineering, geospatial sciences, water resources, and environmental sciences for the Army, the Department of Defense, civilian agencies, and our nation's public good. Find out more at www.erdc.usace.army.mil.

To search for other technical reports published by ERDC, visit the ERDC online library at http://acwc.sdp.sirsi.net/client/default. 


\section{Abiotic Removal of Phosphate From Surface Water - Bench Scale to Meso-Scale}

Carina M. Jung, Jed O. Eberly, G. Alon Blakeney, and Heather M. Knotek-Smith

Environmental Laboratory

US Army Engineer Research and Development Center 3909 Halls Ferry Road

Vicksburg, MS 39180-6199

Final Report

Approved for public release; distribution is unlimited.

Prepared for Headquarters, U.S. Army Corps of Engineers

Washington, DC 20314-1000

Under Project Number 454747 


\section{Abstract}

Cultural eutrophication is a primary cause of impairment to recreational and commercially important waterways. Nutrient loading of waterways through release of fertilizers and sewage, among other substrates high in growth-limiting substrates (phosphorus, nitrogen, and carbon) allows for unchecked growth of photosynthesizers such as blue-green algae (cyanobacteria). Significant cyanobacterial growth may result in plant dieoff, hypoxia, or anoxia, and the proliferation of harmful algal blooms (HABs). Methods exist to bind and inactivate nutrients like phosphorous but these do not remove nutrients from the waterway. This report presents a passive method for physical removal of phosphate $\left(\mathrm{PO}_{4}\right)$ by moving water over reduced iron plates, yielding an iron oxide-phosphate complex that can be passively filtered with sand and activated carbon. Both laband field-scale reactors were tested and compared for phosphate removal rates and performance was evaluated for treating a small contained pond with high phosphate. The reactor configuration presented herein removed phosphate from the experimental pond at a rate of $0.1004 \mathrm{mg} \mathrm{PO}_{4} / \mathrm{L} /$ day. The effectiveness of the treatment method, the ease of installation, low cost, and accessibility of the reactor materials makes this technology an attractive option when binding of free phosphate in surface waters is required.

DISCLAIMER: The contents of this report are not to be used for advertising, publication, or promotional purposes. Citation of trade names does not constitute an official endorsement or approval of the use of such commercial products. All product names and trademarks cited are the property of their respective owners. The findings of this report are not to be construed as an official Department of the Army position unless so designated by other authorized documents. 


\section{Contents}

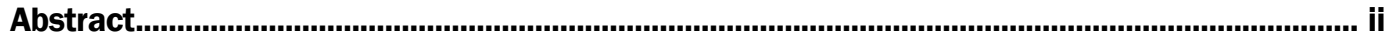

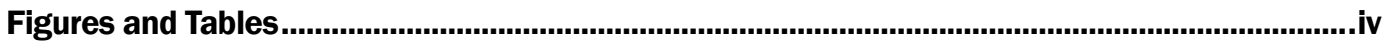

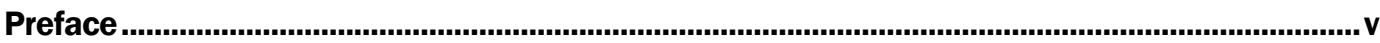

Unit Conversion Factors............................................................................................................ vi

Acronyms and Abbreviations .................................................................................................vii

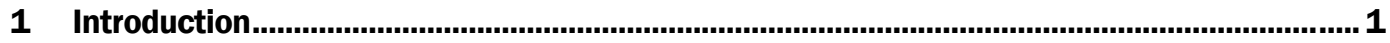

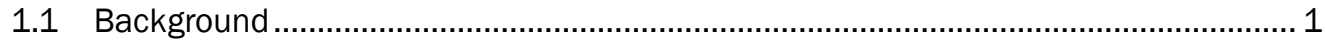

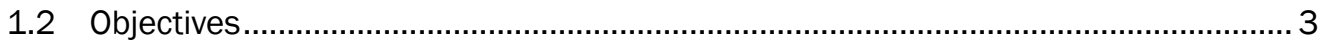

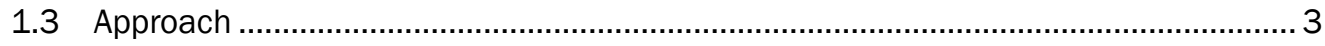

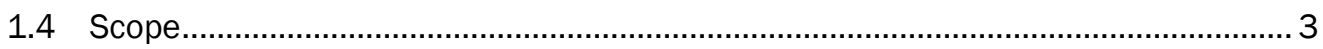

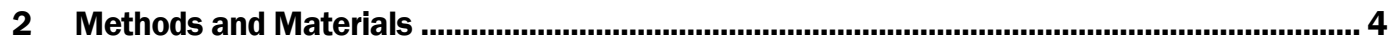

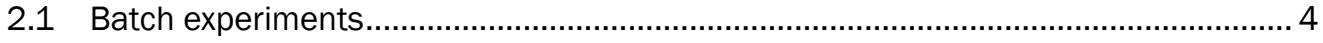

2.2 Adsorption kinetics ......................................................................................... 5

2.3 Bench scale flow through reactor ....................................................................... 5

2.4 Holding pond mesoscale test................................................................................... 6

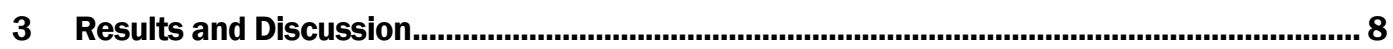

3.1 Batch experiments......................................................................................... 8

3.2 Contact tank experiments ......................................................................... 13

3.3 Holding pond mesoscale test..................................................................... 16

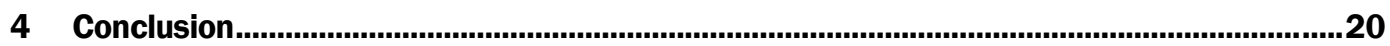

References..........................................................................................................................21

Report Documentation Page 


\section{Figures and Tables}

\section{Figures}

Figure 1. Diagram of the flow path (left) through the bench scale reactor (right).

Figure 2. Holding pond reactor. Flow from far left to far right (left photo). Settling tank and activated carbon/sand filter with outflow to the pond (right photo)..

Figure 3. Batch phosphate adsorption reactions with either iron filings or powder with aquaculture water.

Figure 4. Removal of phosphate from water containing high (left) and low (right) phosphate concentrations in varying concentrations of iron

Figure 5. Phosphate adsorption isotherm for iron filings using the Freundlich Isotherm model, at $22^{\circ} \mathrm{C}$ - in which $K_{F}=36.87$ and $n=2.52$.

Figure 6. Langmuir Isotherm at $22^{\circ} \mathrm{C}-$ in which $a=158.7 \mathrm{mg} \mathrm{PO}_{4}{ }^{3} / \mathrm{g} \mathrm{Fe}$ and $b=0.41 \mathrm{~L} / \mathrm{mg}$.......... 13

Figure 7. Recirculating tank reactor inflow and outflow phosphate measurements. ....................... 14

Figure 8. Comparison of adsorption kinetics with zero, first, and second order kinetic models............. 15

Figure 9. Phosphate uptake vs. flow rate in flow-through tank with aquaculture water..................... 16

Figure 10. Aquaculture flow through phosphate measurements at the inlet and outlet at a constant flow rate of $20 \mathrm{ml} / \mathrm{min}$.

Figure 11. Concentration of phosphate removed over time as measured by the bulk pond water (in) and the reactor effluent (out), and as a ratio of treated/bulk (C/Co). 18

Figure 12. Cumulative phosphate removed from the holding pond over four months.

\section{Tables}

Table 1. Adsorption isotherm measurements. Experiments run with $0.01 \mathrm{~g} \mathrm{Fe}$ in $100 \mathrm{ml}$ test solution.

Table 2. Reaction rate summary 


\section{Preface}

This study was conducted for the U.S. Army Corps of Engineers - Engineer Research and Development Center (USACE-ERDC) Aquatic Plant Control Research Program (APCRP) initiated in FY 2015, "Abiotic Removal of Phosphate From Surface Water - Bench Scale to Meso-Scale, Project Number 454747."

The work was performed by the Environmental Processes Branch (EPP), and the Environmental Engineering Branch (EPE) all of the Environmental Processes and Engineering Division (EPED), U.S. Army Engineer Research and Development Center - Environmental Laboratory (ERDC-EL). At the time of publication, Dr. Brandon Lafferty was the Branch Chief, CEERD-EPP, Dr. W. Andy Martin was Branch Chief, CEERD-EPE, Mr. Warren Lorentz was Division Chief, CEERD-EPED, and Dr. Alfred Cofrancesco, was the Technical Director for Environmental Engineering and Sciences, Civil Works. The Deputy Director of ERDC-EL was Dr. Jack Davis and the Director was Dr. Ilker R. Idiguzel.

COL Ivan P. Beckman was the Commander of ERDC, and Dr. David W. Pittman was the ERDC Director. 


\section{Unit Conversion Factors}

\begin{tabular}{|l|l|l|}
\hline Multiply & By & To Obtain \\
\hline degrees Fahrenheit & $(\mathrm{F}-32) / 1.8$ & degrees Celsius \\
\hline inches & 0.0254 & meters \\
\hline ounces (U.S. fluid) & 2.957353 E-05 & cubic meters \\
\hline
\end{tabular}




\section{Acronyms and Abbreviations}

$\begin{array}{ll}\text { APCRP } & \text { Aquatic Plant Control Research Program } \\ \text { DoD } & \text { Department of Defense } \\ \text { Eh } & \text { Redox potential } \\ \text { EL } & \text { Environmental Laboratory } \\ \text { EPP } & \text { Environmental Processes Branch } \\ \text { EPE } & \text { Environmental Engineering Branch } \\ \text { EPED } & \text { Environmental Processes and Engineering Division } \\ \text { ERDC } & \text { Engineer Research Development Center } \\ \text { g } & \text { Gram } \\ \text { HABs } & \text { Harmful Algal Blooms } \\ \text { h } & \text { hours } \\ \text { L } & \text { Liter } \\ \text { ml } & \text { Milliliter } \\ \text { mm } & \text { Millimeter } \\ \text { min } & \text { minutes } \\ \text { P } & \text { phosphorous } \\ \text { ppm } & \text { parts-per-million } \\ \text { RT } & \text { residence time } \\ \text { USACE } & \text { U.S. Army Corps of Engineers } \\ \end{array}$




\section{Introduction}

\subsection{Background}

Cultural eutrophication is the process of expediting the natural phenomenon of eutrophication through nutrient loading with what are typically growth-limiting substrates (phosphorus, nitrogen, and carbon). An abundance of nutrients, specifically phosphorous (P), can allow for unchecked growth of photosynthesizers such as cyanobacteria (blue-green algae), which is called an algal bloom, or bloom event. Significant cyanobacterial growth may result in reduction in water clarity and light penetration, leading to plant die off, hypoxia, or anoxia. As of a 2008 report, it was estimated that in fifty years hypoxia in marine systems had increased ten-fold globally and thirty-fold in the U.S. (Diaz and Rosenberg 2008). The number of freshwater sources in the U.S. with documented hypoxia has also increased dramatically. Another significant and potentially dangerous issue is the proliferation of toxin-producing cyanobacteria or true algae (i.e., golden algae) into harmful algal blooms (HABs), this can affect morbidity and mortality of aquatic and terrestrial wildlife as well as, domestic animals and humans.

Overall, eutrophication is a primary cause of impairment to recreational and commercially important waterways (Chislock et al. 2013). Current approaches to the algal bloom problem have been reactionary, finding ways to battle the already entrenched blooms. Unfortunately, this is a symptom of an ongoing problem. In most cases, agricultural or municipal runoff is the cause and $\mathrm{P}$ and $\mathrm{N}$ are the predominant nutrients released into these waterways. $\mathrm{P}$ is considered the predominant growth limiting nutrient since many cyanobacteria can fix atmospheric nitrogen (Kortsee et al. 1994). Numerous regulations have been introduced to curb nutrient input into surface waters, including reductions in P-containing fertilizers for municipal and commercial use, and public education (summarized at https://www.epa.gov/nutrient-policy-data/what-epa-doing-reduce-nutrient-pollution). Other means for combating eutrophication and HABs have included algaecide and herbicide application, and decreasing the photosynthetic ability of aquatic life through shading or additive obscurants like dyes (Chislock et al. 2013). These methods are moderately effective, temporary measures, as they do not address the issue of high nutrient input. 
Nutrient input limitation and control can be managed, this generally involves limiting nitrogen and/or phosphorous by a variety of methods. Physical removal of these nutrients from the waterway or watershed is a more permanent solution to reducing nutrient loads. Dredging removes impacted, nutrient rich sediment, but it is expensive, may have numerous ecological impacts, and is ineffective in a system receiving constant nutrient input. Nutrient traps use vegetation to sequester nutrients, often in inlets, prior to discharge into a lake/reservoir. These traps are ecologically sound and inexpensive but take site-specific planning and long-term management. Algal scrubbers are an ingenious way to remove total phosphorous from affected waters. The design concept is to introduce relatively safe algae trapped in a matrix (scrubbers) to nutrient rich water which is pumped from the affected site through the scrubber. The algae rapidly grow, sequestering nutrients, while $\mathrm{Ca}$ is added to precipitate excess phosphorous/phosphate (Sindelar et al. 2015).

Probably the most widely used method of nutrient reduction is the addition of clay, aluminum, copper sulfate, or iron coagulants. Dissolved nutrients bind these added particles and settle out of the water column into the sediment. This method is effective in small areas (Kim 2012), but the nutrients are only sequestered, leaving the long-term effectiveness in question. There are other issues such as $\mathrm{pH}$ perturbation or toxicity if excessive coagulants are added (U.S. Army Corps of Engineers (USACE) et al. 2008).

Iron, in its many forms and complexes, is an efficient chelator of phosphate that has been shown in some cases to bind irreversibly (Barber 2002). Iron has been used in bioremediation, waste and contaminant removal, and in water treatment as a tool to either bind unwanted compounds or elements, or as a reactive chemical matrix to shuttle electrons in redox reactions (Fredrickson and Gorby 1996). A variety of iron substrate complexes have been studied ranging from iron-doped activated carbon to iron-hydroxide complexed with egg shells (Mezenner and Bensmaili 2009; Wang et al. 2012). These efforts highlight the need for an efficient, cost effective method for environmental phosphate removal. While the kinetics of phosphate adsorption on pure iron oxides have been well studied (Liu and Huang 2000), pure iron oxides are not a cost effective source for phosphate removal on an environmental scale and binding efficiency is confounded by other ions present in environmental water sources. 


\subsection{Objectives}

This study describes a simple, alternative method for removing phosphate from water in a flow through configuration. The phosphate iron binding experiments started at batch bench scale and continued with a meso-scale continuous flow reactor.

\subsection{Approach}

In this work, the team treated water impacted by high phosphate levels using iron-metal plates in a flow-through reactor. The reactor design for field scale application featured a finishing step, whereby iron and phosphate particulates were captured and removed from the system with a passive activated carbon and sand filter.

\subsection{Scope}

The study evaluated iron powder, iron filings, and iron plates, and found minimal differences in their abilities to effectively bind the phosphate. 


\section{Methods and Materials}

\subsection{Batch experiments}

Initial batch experiments were performed to determine the phosphate binding capacity and rates for two different iron size distributions. Iron powder (80-100 mesh, Fisher Scientific) and iron filings (40-60 mesh, Fisher Scientific) at $0.5 \%$ (weight/volume) were each added to 50 milliliter (ml) flasks containing $40 \mathrm{ml}$ aquaculture water from the carp rearing facility at Engineer Research Development Center (ERDC). Aquaculture water was chosen as a test case since it is one of the foreseeable applications of the treatment strategy being considered. Flasks were swirled once, then left at room temperature without agitation. Control flasks without iron were also established and all conditions were performed in triplicate. Phosphate was monitored for 145 hours (h), at this time, the sample water was replaced from the experimental flasks with fresh water. The flasks were monitored until phosphate was 90\% depleted (214 h), fresh water was again replaced, and phosphate monitored until $337 \mathrm{~h}$ when phosphate was $90 \%$ depleted. $\mathrm{pH}$ was monitored at the start and finish of the experiment and found to be between 6.5-7.5. Redox potential (Eh) was not monitored.

Phosphate was monitored colorimetrically with a LaMotte Series 1200 colorimeter (LaMotte Company, Chesterton, MD.) as $O$-phosphate (will be called phosphate throughout the report) via the ascorbic acid method which utilizes ammonium molybdate and antimony potassium tartrate. Reagents and methods were provided with the LaMotte Series 1200 instrument. Limits of detection were between 0.01-3 parts-per-million (ppm). Samples with concentrations above $3 \mathrm{ppm}$ were diluted appropriately in phosphate free water.

Degreased iron filings (Fisher Scientific) and iron powder (North American Höganäs) were added to flasks at 0.02, 0.2, and 2\% (weight/volume) with two concentrations of phosphate ( $\sim 25 \mathrm{ppm}$ and diluted to $2.5 \mathrm{ppm}$ ) to determine rates of phosphate binding in aquaculture water at low and high phosphate concentrations. These flasks were shaken at $20^{\circ} \mathrm{C}$, monitored over time, and the rates for phosphate sorption were determined over $145 \mathrm{~h}$. 


\subsection{Adsorption kinetics}

Adsorption kinetic experiments (Hussain et al. 2003; Keum and Li 2004; Son et al. 2006) were performed using seven phosphate concentrations from 0.25 to $100 \mathrm{ppm}$ with iron filings. Flasks were prepared with $100 \mathrm{ml}$ of $5 \mathrm{mM} \mathrm{NaCl}$ and $0.01 \% \mathrm{Fe}$ (0.01 grams (g) iron filings) each at $\mathrm{pH} 7$, in triplicate. Salt was included since saline conditions can improve adsorption at neutral $\mathrm{pH}$ (Spiteri et al. 2008). The flasks were allowed to shake gently at $100 \mathrm{rpm}$ and $22^{\circ} \mathrm{C}$ for $36 \mathrm{~h}$. pH was monitored throughout and found to be constant.

Once phosphate binding rates and capacities were determined for different iron particle sizes, a simple packed bed reactor was designed to determine the feasibility of using a flow through system with a short residence time for iron-phosphate binding. Iron pellets (4 millimeter ( $\mathrm{mm}$ ) maximum, Sigma) were added at $0.1 \%$ ( $4 \mathrm{~g}$ ) to the end of a $5 \mathrm{ml}$ glass pipette stoppered with loose cotton plugs. A four Liter (L) volume of dilute aquaculture water $\left(3.3 \mathrm{ppm} \mathrm{PO}_{4}\right)$ was recirculated through the column at a flow rate of $60 \mathrm{ml} /$ minutes (min), for a total treatment time of $67 \mathrm{~min}$.

\subsection{Bench scale flow through reactor}

Following the successful demonstration of phosphate removal in a flow through system, scale up experiments were performed with a $45 \mathrm{~L}$ continuous flow contact tank (reactor). Ten, cold-rolled, plain steel sheets with Grecian pattern holes (35\% open space, McNichols, Co, Garland, TX.) measuring $12 \times 12 \times 0.0625 \mathrm{in}$. with approximately $1.3 \mathrm{ft}^{2}$ surface area per plate were acid etched to remove finishing grease and provide a reactive surface. The plates were placed in a $45 \mathrm{~L}$, baffled rectangular acrylic glass vessel (Figure1). The vessel interior was $12.5 \mathrm{in}$. wide by $23 \mathrm{in.} \mathrm{long} \mathrm{(3} \mathrm{in.}$ inlet, 16 in. contact, and 7 in. outlet) with a 9.5 in. water depth. Baffles with staggered hole patterns were located throughout the tank to support the metal sheets and to ensure complete mixing. Effective mixing was verified by dye tracer tests (data not shown). The tank was filled with dilute aquaculture facility water ( $2.8 \mathrm{ppm}$ phosphate) and recirculated at $300 \mathrm{ml} / \mathrm{min}$, for a residence time (RT) of $2.48 \mathrm{~h}$. Phosphate concentrations were measured at $0,3,21$, and $27 \mathrm{~h}$, the reactor was run for $27 \mathrm{~h}$ ( $\sim 11$ reactor volumes), at this time $>90 \%$ of the phosphate was depleted from the water. The rate of phosphate removal was calculated at $57 \mu \mathrm{g}$ $\mathrm{PO}_{4} / \mathrm{L} / \mathrm{h}$. 
After determining the rates of phosphate removal, the bench scale reactor was reconfigured for flow through treatment without recycling to determine the treatment capacity. The reactor was fed with diluted aquaculture water and configured with twenty expanded metal plates, a $20 \mathrm{ml} / \mathrm{min}$ flow rate was used which was based on the phosphate binding rates that were previously established. Phosphate was monitored for $\sim 500 \mathrm{~h}$ (21 days) during which the binding rates were relatively consistent. Samples were taken at the influent and effluent and these data were compared at each time point since phosphate input levels in the aquaculture facility were not constant.

Figure 1. Diagram of the flow path (left) through the bench scale reactor (right).

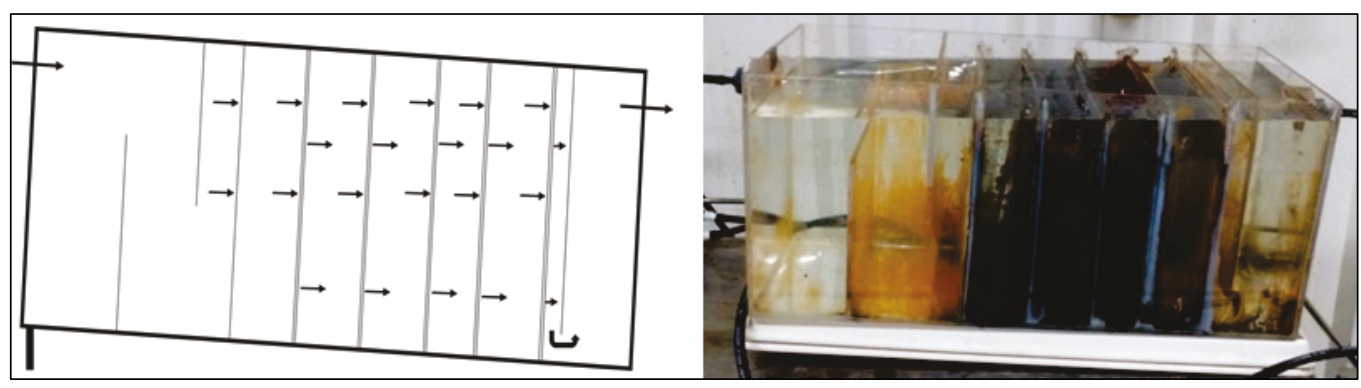

\subsection{Holding pond mesoscale test}

Following the successful bench scale treatment, a pilot scale test was also performed. A holding pond with a volume of approximately 90,600 L was spiked with $\mathrm{KH}_{2} \mathrm{PO}_{4}$ resulting in a phosphate concentration of $14 \mathrm{ppm}$ (Figure 2). A test reactor with a volume of $226.5 \mathrm{~L}$ ( $2 \times 1 \times 4 \mathrm{ft}$ ) was constructed holding ten plates. The plates were set two across with a contact area of $2 \mathrm{ft}^{2} \times 0.5 \mathrm{ft}$ in length. The effluent of the contact reactor was fed into a settling tank followed by a packed bed filter. The settling tank feed was introduced into the settling tank at $1.5 \mathrm{ft}$ above the cone bottom and exited at a height of $3 \mathrm{ft}$, the tank diameter was $2 \mathrm{ft}$ (total volume of $260 \mathrm{~L}$ ). The packed bed filter consisted of a 2 x 1 x $4 \mathrm{ft}$ Plexiglas tank filled with a mixture of $490 \mathrm{lbs}$ of sand and $83 \mathrm{lbs}$ of activated carbon. The packing was reinforced with rock weirs spaced every foot along the length. The phosphate water was fed from the pond through the reactor system and was then fed back into the pond. The flow rate averaged $620 \mathrm{ml} / \mathrm{min}$ over 127 days during which the phosphate levels were measured approximately three times a week. 
Figure 2. Holding pond reactor. Flow from far left to far right (left photo). Settling tank and activated carbon/sand filter with outflow to the pond (right photo).

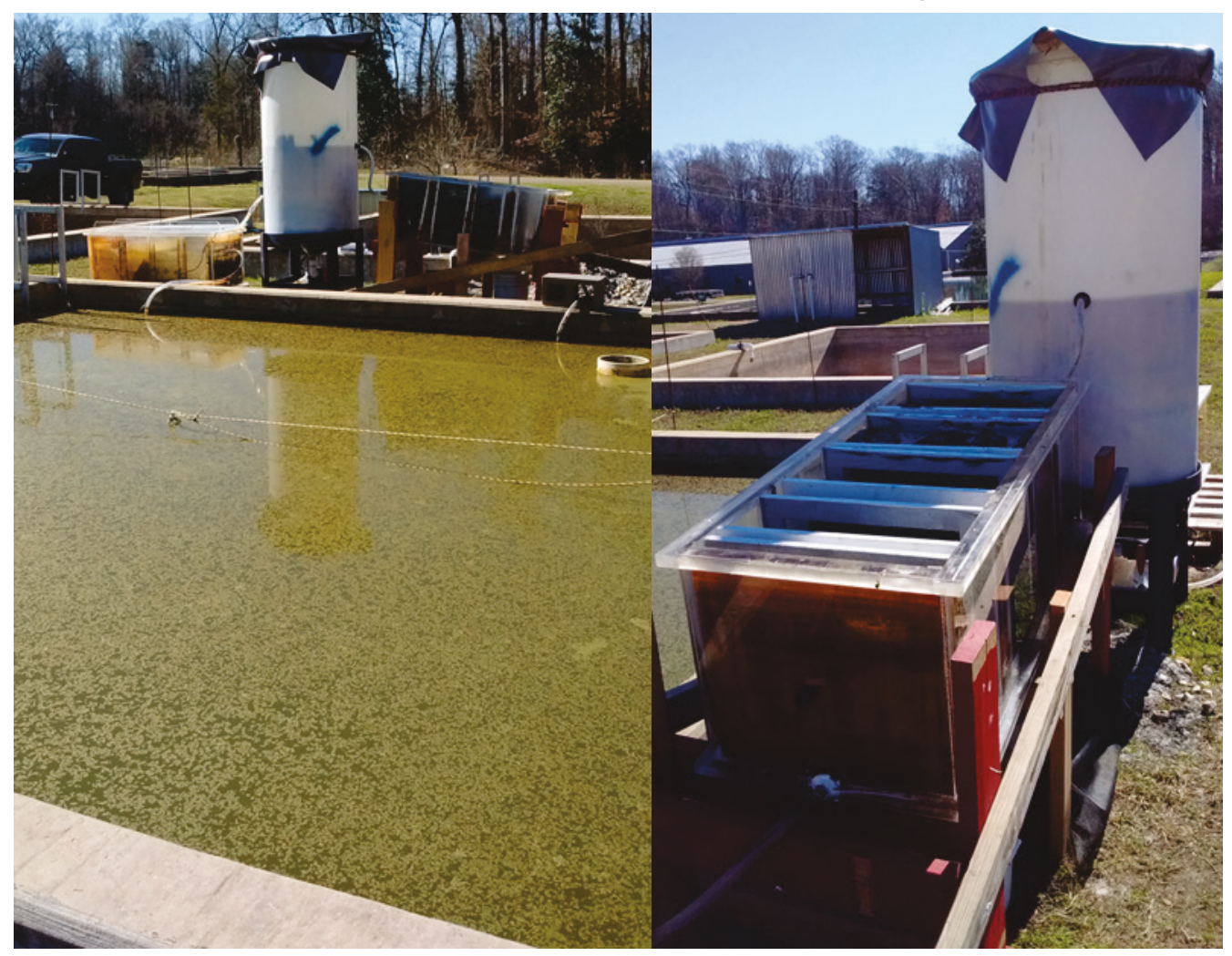




\section{Results and Discussion}

\subsection{Batch experiments}

Initial batch experiments were performed to determine the phosphate binding capacity of iron powder and iron filings (80-100 and 40-60 mesh, respectively). Binding capacity at $0.5 \%(\mathrm{w} / \mathrm{v})$ was determined using aquaculture water $(\sim 25 \mathrm{ppm})$. After $45 \mathrm{~h}$ without agitation $>90 \%$ of the phosphate had been taken out of solution and remained bound to the iron particles (Figure 3). The liquid in the flasks was decanted and replaced with fresh water twice, sequentially, and each time the phosphate was again removed by $>90 \%$. The ratio of $\mathrm{Fe}: \mathrm{PO}_{4}$ being employed was 1500:1 which is highly saturated with iron as compared with other studies where binding capacity for phosphate to iron shows that at 56:1 Fe: $\mathrm{PO}_{4}$ there was 98\% uptake (Lijklema 1980; Rich 2005). There was no difference in binding capacity between the two particle sizes of Fe at this saturated concentration, therefore, only filings were used for the subsequent experiments. The phosphate adsorption kinetic data was fitted with the first-order kinetic models by non-linear regression using SigmaPlot 12.5 software. The kinetic equation can be written as

$$
\frac{A}{A_{0}}=e^{-k t}
$$

where,

$$
\begin{aligned}
T & =\text { time elapsed }(\mathrm{h}) \\
A_{o} & =\text { initial phosphate concentration }\left(\mathrm{mg} \mathrm{PO}_{4} / \mathrm{L}\right), \\
A & =\text { phosphate concentration at time }\left(\mathrm{mg} \mathrm{PO}_{4} / \mathrm{L}\right), \\
K & =\text { adsorption rate constant for the model }\left(\mathrm{h}^{-1}\right)
\end{aligned}
$$


Figure 3. Batch phosphate adsorption reactions with either iron filings or powder with aquaculture water.

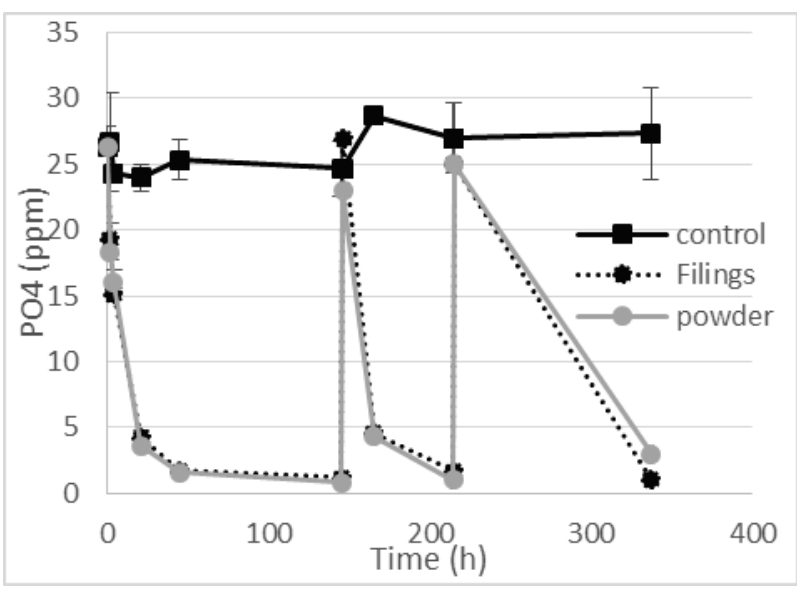

The reaction rate for the powder and iron filings sorption were $0.008 \mathrm{~h}^{-1}$ and $0.006 \mathrm{~h}^{-1}$ with an $R^{2}$ of 0.97 and 0.86 , respectively. Range finding studies to determine upper and lower limits of phosphate binding were performed to determine the optimum amount of iron needed for a given phosphate concentration. Water with lower phosphate levels (2.5 ppm) showed little difference in phosphate binding over a 100-fold range of iron concentrations (Figure 4). The higher phosphate level water (26 ppm) showed differential binding with $10 \mathrm{ppm}$ of phosphate remaining at the lowest (0.02\%) iron concentration (Figure 4).

Figure 4. Removal of phosphate from water containing high (left) and low (right) phosphate concentrations in varying concentrations of iron.
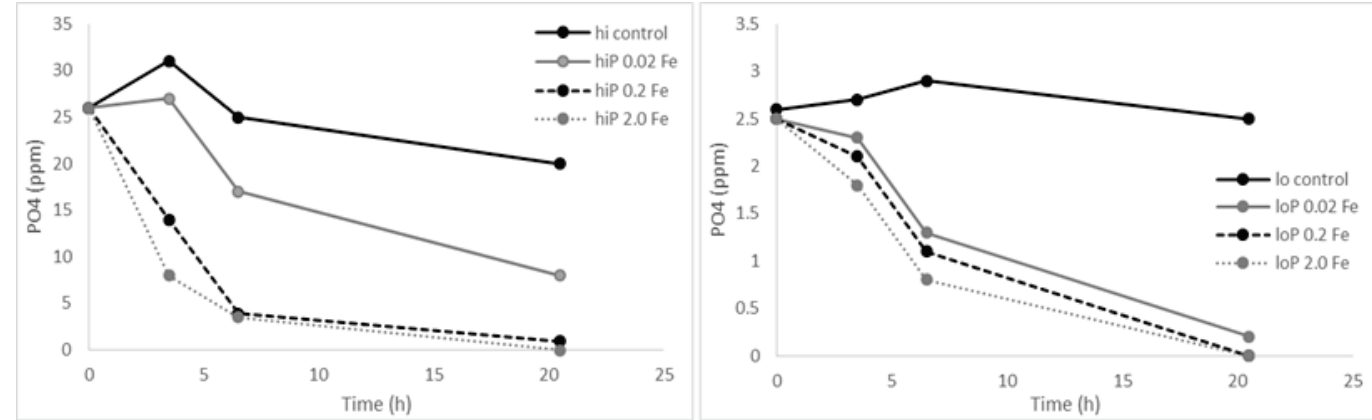

Adsorption efficiency was evaluated using a range of $\mathrm{PO}_{4}$ concentrations from 0.25 and $25 \mathrm{ppm}$ incubated with $0.1 \mathrm{mg}$ Fe filings/L. After addition of the Fe, phosphate concentrations were periodically measured and steady state was reached at $36 \mathrm{~h}$. Isotherm data is shown in Table 1. The adsorption isotherm was calculated (Equation 2) using the Freundlich model which assumes monomolecular coverage with a heterogeneous valence distribution (Figure 5) (Al-Asheh et al. 2000) 


$$
q_{e}=K_{F} C_{e}^{\frac{1}{n}}
$$

where,

$K_{F}=$ constant related to the adsorption capacity $(\mathrm{mg} / \mathrm{g})$, $1 / n=$ empirical constant related to the adsorption intensity,

$C_{e}=$ equilibrium concentration of phosphate $(\mathrm{mg} / \mathrm{L})$,

$q_{e}=$ adsorption capacity adsorbed at equilibrium.

Table 1. Adsorption isotherm measurements. Experiments run with $0.01 \mathrm{~g} \mathrm{Fe}$ in $100 \mathrm{ml}$ test solution.

\begin{tabular}{|c|c|c|c|}
\hline \multicolumn{2}{|c|}{$\mathrm{PO}_{4}{ }^{3-}$ (mg/L) } & \multirow{2}{*}{\begin{tabular}{|l|}
$\mathrm{PO}_{4}{ }^{3-}$ sorbed \\
$\mathrm{mg} \mathrm{PO}_{4}{ }^{3-} / \mathrm{g} \mathrm{Fe}$ \\
\end{tabular}} & \multirow[b]{3}{*}{$\mathrm{Ce} / \mathrm{q}$} \\
\hline$t=0 h$ & $t=36 \mathrm{~h}$ & & \\
\hline & $\mathrm{Ce}$ & qe & \\
\hline 0.30 & 0.003 & 2.97 & 0.0011 \\
\hline 0.53 & 0.010 & 5.20 & 0.0019 \\
\hline 2.51 & 0.157 & 23.53 & 0.0067 \\
\hline 5.00 & 0.567 & 44.33 & 0.0128 \\
\hline 10.70 & 4.567 & 61.33 & 0.0745 \\
\hline 25.00 & 13.567 & 114.33 & 0.1187 \\
\hline 100.00 & 84.333 & 156.67 & 0.5383 \\
\hline
\end{tabular}


Figure 5. Phosphate adsorption isotherm for iron filings using the Freundlich Isotherm model, at $22^{\circ} \mathrm{C}$ - in which $K_{F}=36.87$ and $n=2.52$.

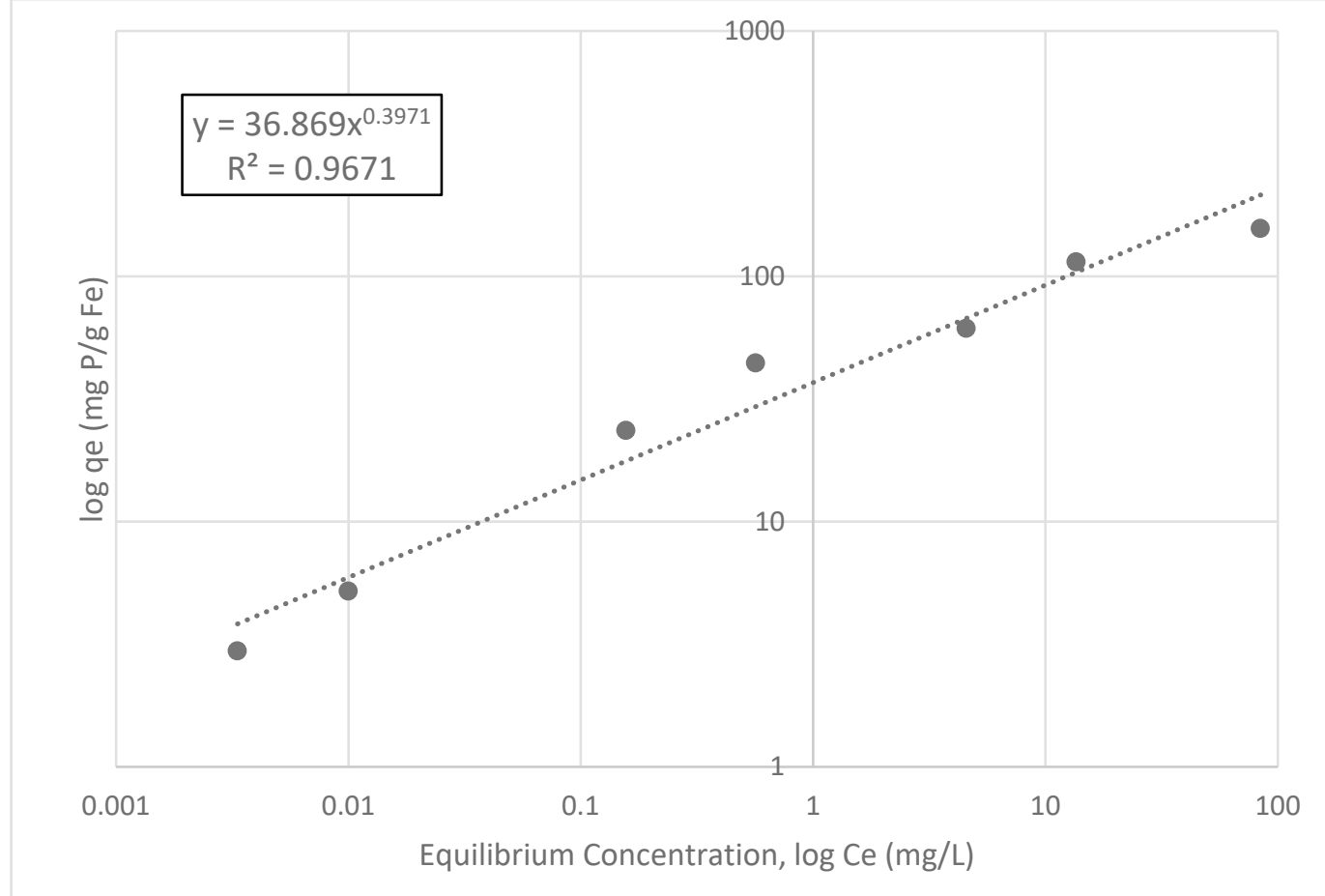

The constants in the Freundlich isotherm can be determined through linearization of Equation 2 by taking the logarithm of both sides as in Equation 3 (Metcalf and Eddy 1991)

$$
\log q_{e}=\log K_{F}+\frac{1}{n} \log C_{e}
$$

The sorption data was plotted on a $\log _{10} \log$ scale with $C e$ on the $x$ axis and $q e$ on the $y$ as shown in Figure 5. The linear equation fit to the adsorption data is $y=0.0369 \mathrm{x}^{0.3971}$ with an $R^{2}=0.9671$. From this fit $K_{F}$ and $n$ were determined to be 0.0369 and 2.52, respectively. Values obtained of $1<\mathrm{n}<$ 10 imply favorable sorption of phosphate ions on the iron surface (Metcalf and Eddy 1991) and is comparable to the adsorption intensity reported by Wang et al. (2012).

The adsorption isotherm was also calculated using the Langmuir Adsorption Isotherm as defined as in Equation 4 (Metcalf and Eddy 1991)

$$
q_{e}=\frac{a b c_{e}}{1+b c_{e}}
$$


The linear form of the Langmuir equation at a given temperature is represented by Equation 5

$$
\frac{C_{e}}{q_{e}}=\frac{1}{a b}+\frac{C_{e}}{a}
$$

where,

$C_{e}=$ aqueous phase equilibrium concentration $(\mathrm{mg} / \mathrm{L})$,

$q_{e}=$ amount of phosphate sorbed onto $1 \mathrm{~g}$ of iron,

$a=$ maximum sorption capacity $(\mathrm{mg} / \mathrm{g})$,

$b=$ sorption constant $(\mathrm{L} / \mathrm{mg})$ related to the energy of sorption.

The sorption data was plotted with $C_{e}$ on the x axis and $C_{e} / q_{e}$ on the $y$ axis as shown in Figure 6. The linear equation fit to the adsorption data is $y=$ $0.0063 x+0.0155$ with an $R^{2}=0.9921$. From Equation 5 , the sorption constant $b$ is $0.41 \mathrm{~L} / \mathrm{mg}$ and the maximum sorption capacity $a$ of the iron filings is $158.7 \mathrm{mg} \mathrm{PO}_{4} 3^{-/ g}$.

The Langmuir adsorption isotherm was developed assuming that the sorption surface had a fixed number of accessible sites (Metcalf and Eddy 1991). Due to the high $R^{2}$ with a linear fit of the data, it can be assumed that the iron surface was not saturated during the $36 \mathrm{~h}$ test. This is not true during flow through experiments in which iron oxides are being removed by the water flow. 
Figure 6. Langmuir Isotherm at $22^{\circ} \mathrm{C}-$ in which $a=158.7 \mathrm{mg} \mathrm{PO}_{4}^{3-} / \mathrm{g} \mathrm{Fe}$ and $b=0.41 \mathrm{~L} / \mathrm{mg}$.

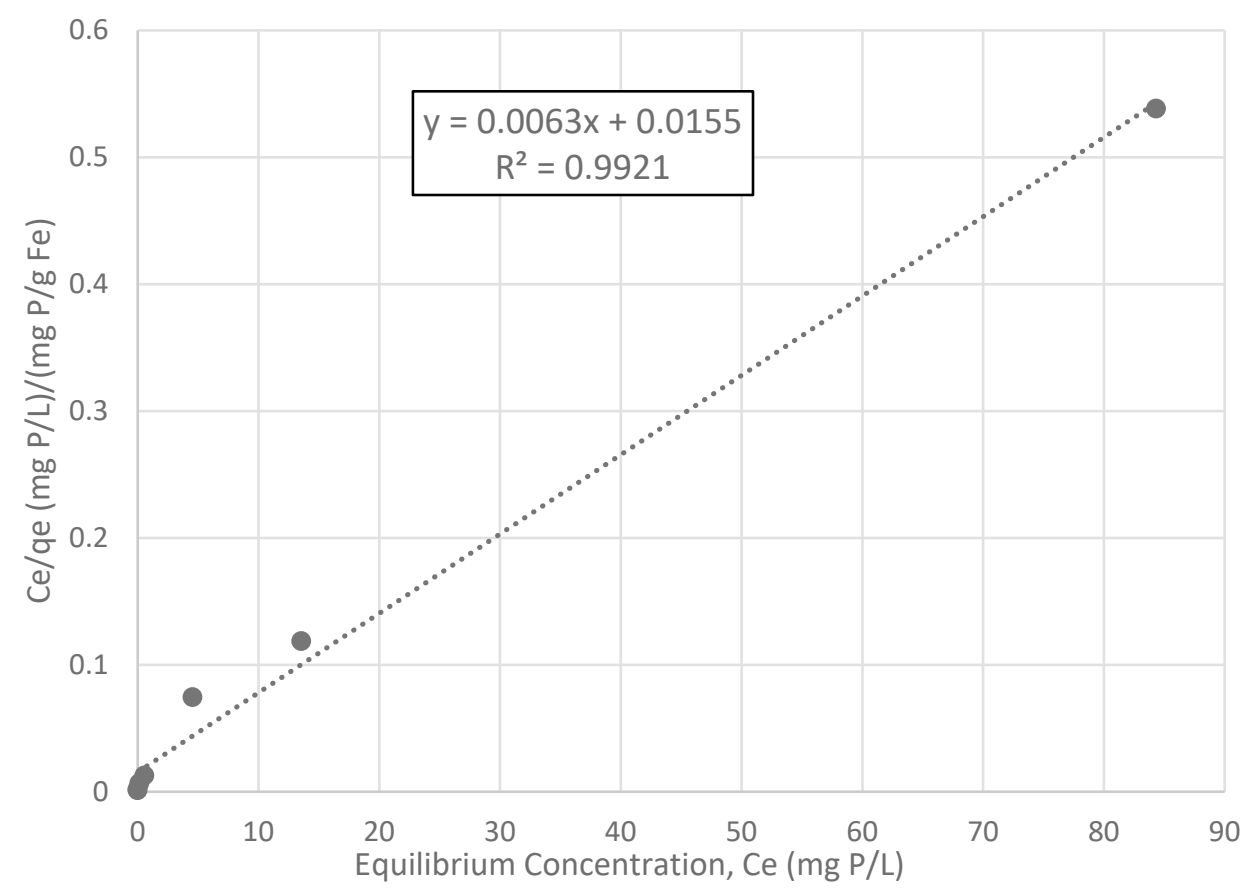

\subsection{Contact tank experiments}

In addition to determining the adsorption equilibrium, the reaction kinetics were modeled to determine the kinetic model that best described the system. The recirculating design was scaled up 10-fold to a 40-L reactor (Figure 1) with steel plates, this was to be used in a first field trial. Initial tests presented here were conducted before fielding this reactor. The reactor inlet and outlet were monitored, although the measurements were redundant due to the recirculating design. By $27 \mathrm{~h}$ there was $>90 \%$ reduction in phosphate with a phosphate removal rate of $56.5 \mu \mathrm{g} / \mathrm{L} / \mathrm{h}$ (Figure 7). The adsorption kinetics were analyzed as zero, first, and second order kinetics in Matlab R2017a to determine the best fit reaction kinetic model. A zero order kinetic model was fit using Equation 6

$$
A=A_{o} \pm K t
$$

Where,

$T=$ time elapsed $(\mathrm{h})$,

$A_{o}=$ initial phosphate concentration $\left(\mathrm{mg} \mathrm{PO}_{4} / \mathrm{L}\right)$,

$A=$ phosphate concentration at time $\mathrm{t}\left(\mathrm{mg} \mathrm{PO}_{4} / \mathrm{L}\right)$,

$K=$ adsorption rate constant for the model $\left(\mathrm{mg} \mathrm{PO}_{4} / \mathrm{L}^{-\mathrm{h}^{-1}}\right)$. 
A second order kinetic model was fit using Equation 7

$$
A=\frac{A_{o}}{\left(1+K t A_{o}\right)}
$$

Where,

$$
\begin{aligned}
t & =\text { time elapsed }(\mathrm{h}), \\
A_{o} & =\text { initial phosphate concentration }\left(\mathrm{mg} \mathrm{PO}_{4} / \mathrm{L}\right), \\
A & =\text { phosphate concentration at time } \mathrm{t}\left(\mathrm{mg} \mathrm{PO}_{4} / \mathrm{L}\right), \\
K & =\text { adsorption rate constant for the model }\left(\mathrm{mg} / \mathrm{PO}_{4} / \mathrm{L} \mathrm{h}^{-1}\right) .
\end{aligned}
$$

The rate constant $K$ for the recirculating plate reactor with a zero order kinetic model was $0.057\left(\mathrm{mg} / \mathrm{PO}_{4} / \mathrm{L} \mathrm{h}^{-1}\right)$, with an $R^{2}$ of 0.96 , and the first order fit (Equation 1) rate constant was $0.086 \mathrm{~h}^{-1}$ with an $R^{2}$ of 0.66 . This rate constant was similar to the rate constants for the iron powder and filings which were $0.0837 \mathrm{~h}^{-1}$ and $0.0768 \mathrm{~h}^{-1}$, respectively. The rate constant for the second order kinetic model was $0.169\left(\mathrm{mg} / \mathrm{PO}_{4} / \mathrm{L} \mathrm{h}^{-1}\right)$ with an $R^{2}$ of 0.53. The best fit based on $R^{2}$ values was obtained with a first order reaction (Figure 8). In contrast, other reports of phosphate adsorption have found that a pseudo-second order model provides the best fit (Liu and Huang 2000; Mao and Yue 2016). This difference could be due to the fact that iron plates were used in this study instead of $\mathrm{Fe}$ (III) as $\mathrm{FeCl}_{3}$ (Mao and Yue 2016) and Fe(II) as ferrous chlorate (Liu and Huang 2000).

Figure 7. Recirculating tank reactor inflow and outflow phosphate measurements.

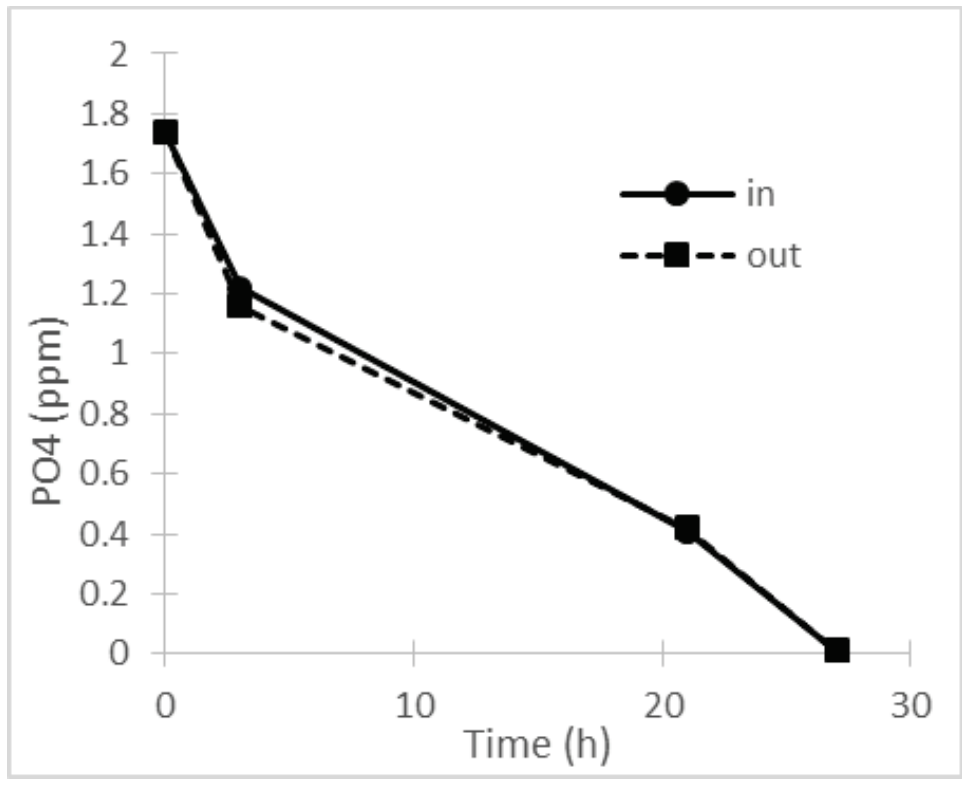


Figure 8. Comparison of adsorption kinetics with zero, first, and second order kinetic models.

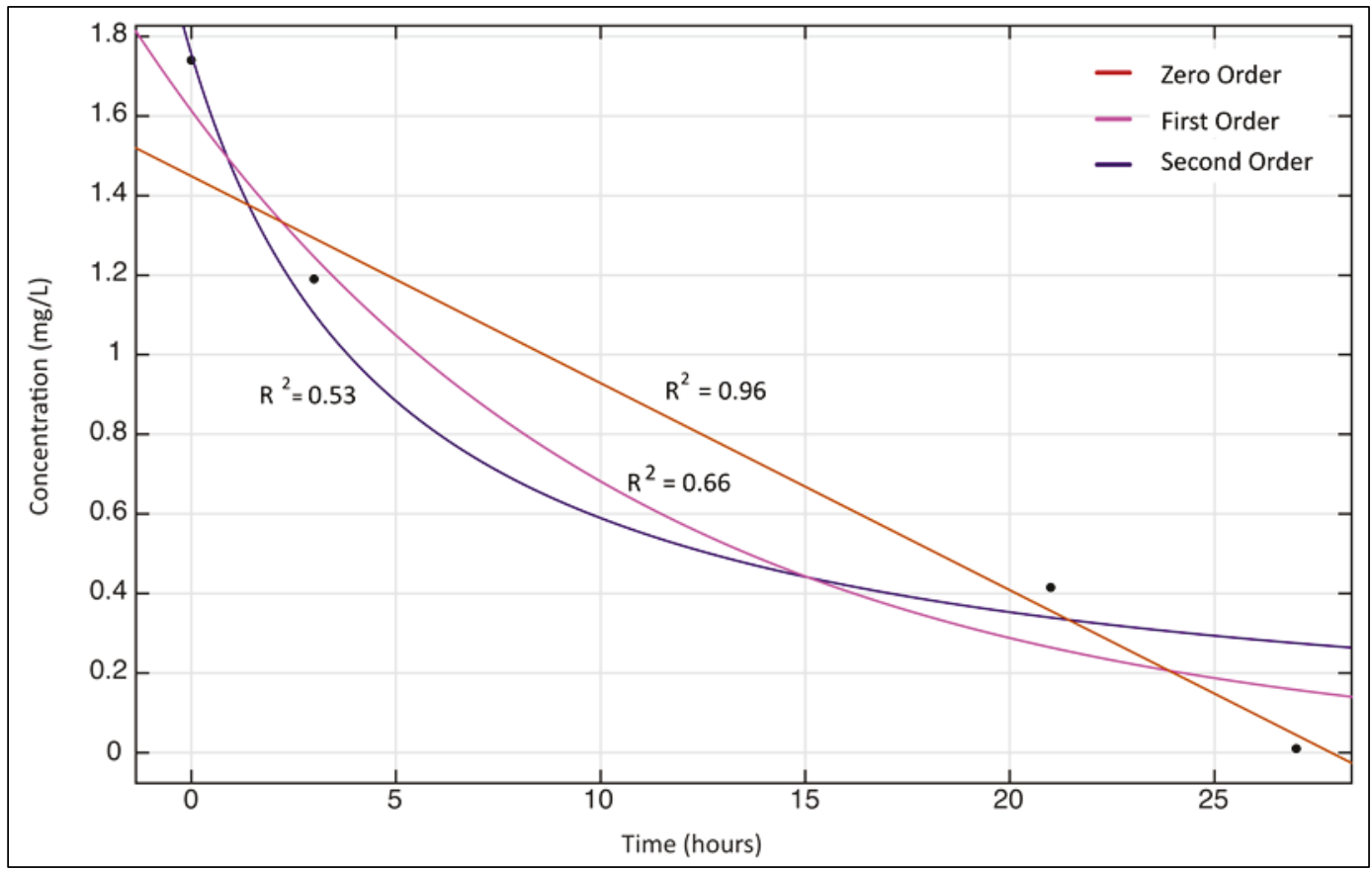

The reactor was then reconfigured for a one pass flow-through for flow rate optimization. A feed tank containing dilute aquaculture water with phosphate levels below $2 \mathrm{ppm}$ was used for each experimental run. Separate, short term $(<7 \mathrm{~h})$ flow-through experiments were conducted whereby phosphate was monitored at the reactor inlet and outlet. This was repeated at different rates and the average phosphate removal for each flow rate was compared and data were reported as the percent of phosphate bound relative to the lowest ( $40 \mathrm{ml} / \mathrm{min}$ ) flow rate. No significant differences were observed in the percent phosphate removal up to $200 \mathrm{ml} / \mathrm{min}(\mathrm{p}<0.001)$ (Figure 9). A lower flow rate $(20 \mathrm{ml} / \mathrm{min}$ ) was then tried for a longer term flow through experiment using a dilute aquaculture feed tank with variable phosphate levels (0.5-4.5 ppm). Phosphate concentrations were monitored at the inlet and outlet for 500 $\mathrm{h}$. The reduction in phosphate was relatively constant throughout the entire experiment, this indicated that the binding capacity of metal plates were not saturated over the course of the experiment (Figure 10). It was not possible to determine the binding capacity of the iron plates over the course of the experiment This is because for iron, the process of phosphate removal is the formation of hydrous ferric oxides, followed by phosphate adsorption (Mao and Yue 2016). This suggests that the plates would function as a constant supply of iron oxide to complex with available phosphate. Thus, the plates would be gradually oxidized over time rather 
than reaching a state where the surface was saturated. This explanation is further supported by the rust color of the water, indicating oxidized iron was being lost from the surface of the plates.

Figure 9. Phosphate uptake vs. flow rate in flow-through tank with aquaculture water.

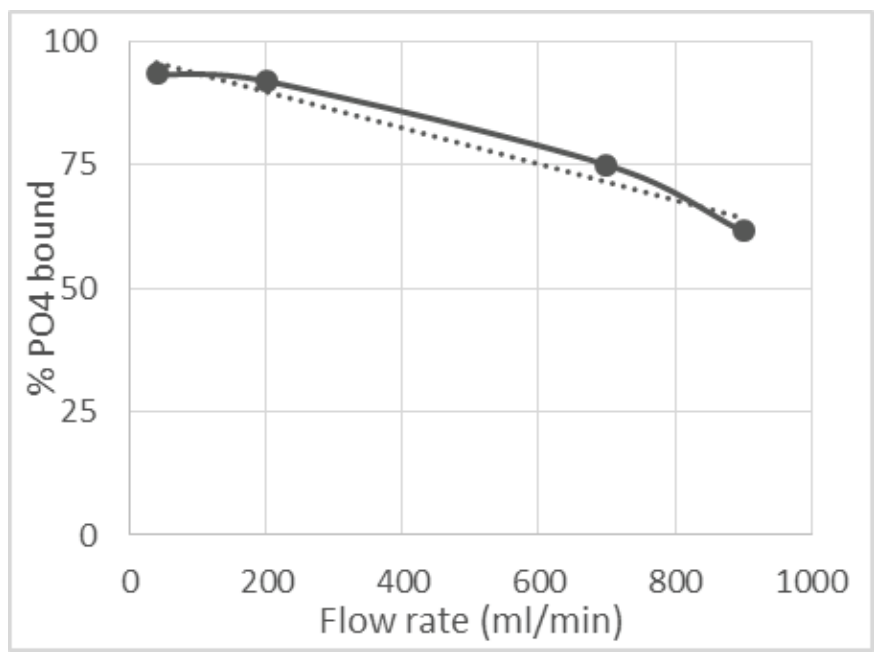

Figure 10. Aquaculture flow through phosphate measurements at the inlet and outlet at a constant flow rate of $20 \mathrm{ml} / \mathrm{min}$.

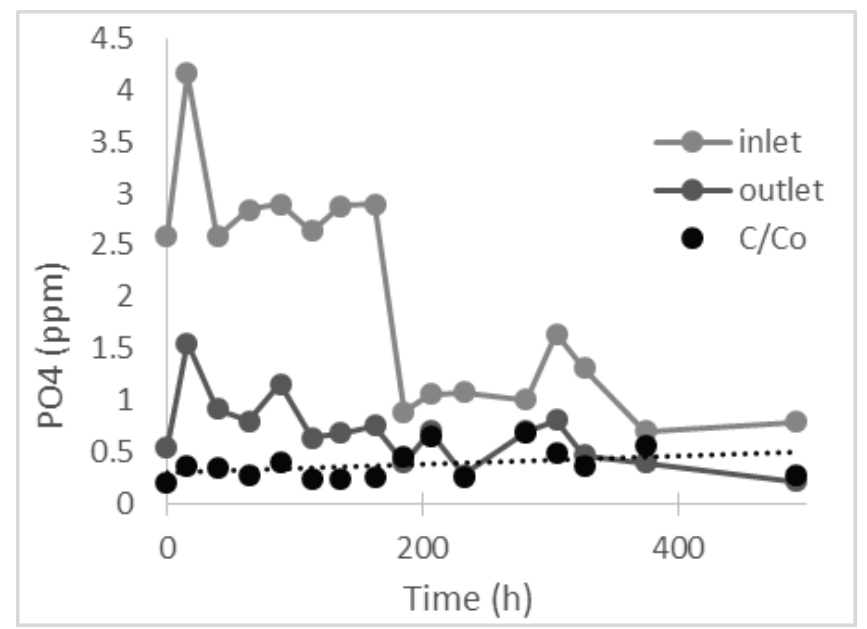

\subsection{Holding pond mesoscale test}

The phosphate levels in the pond decreased from $14.4 \mathrm{ppm}$ to $1.2 \mathrm{ppm}$ during the test period as shown in Figure 11. The phosphate levels dropped rapidly in the first 20 days from $14.4 \mathrm{ppm}$ to $7.8 \mathrm{ppm}$, then $5 \mathrm{ppm}$ at 40 days, and $4.5 \mathrm{ppm}$ at 60 days. It was expected that the total mass removed daily from the reactor flow would decrease as the concentration decreased, due to the resulting decrease in direct phosphate/iron contact, however, 
the reactor site was disrupted by weather and plant growth confounding the phosphate uptake results.

The total mass of phosphate removed from solution based on pond concentration was $1.2 \mathrm{~kg}$ phosphate, however, only $65 \mathrm{~g}$ can be directly attributed to the reactor through flow concentration measurements, as shown in Figure 12. This cumulative number was determined by measurement of the inlet and the outlet of the reactor assuming a constant flow of $620 \mathrm{ml} / \mathrm{min}$ over the 127 days. Late in the experiment, the removal of phosphate seemed to stall and the concentration in the pond did not decrease to a significant degree. The experiment reached day 100 in late May and the pond and the bioreactor were experiencing significant biological growth. Efforts were made to clean the plates and renew the reactive surface, but phosphate removal did not reestablish reliably as the biological growth quickly regenerated.

The other 1,135 $\mathrm{g}$ of phosphate ( $65 \mathrm{~g}$ from reactor and 1,135 $\mathrm{g}$ undefined for a total of $1.2 \mathrm{~kg}$ phosphate) may have been in part removed by the reactor, may have been bound by free iron leaking out of the sand filter back into the holding pond, or by plant growth. Early in the reactor testing cycle, large rain events flooded the sand filter causing an overflow of sand and iron particulates into the holding cell. The system was treated as a large batch reactor with a given mass of phosphate requiring contact with the iron surface. The analysis was done as a batch, rather than a flow through reactor, due to the fact that not all of the phosphate binding was being accomplished within the reactor vessel, but was also occurring within the pond due to iron leaking and plant growth as previously discussed. However, the kinetics of the phosphate removal for the pond, as analyzed as a batch system, was removed at a first order reaction rate with a reaction rate constant of $0.100 \mathrm{mg} / \mathrm{L} /$ day with an $\mathrm{R}^{2}$ of 0.91 . Reaction rates were calculated using a first order reaction model (Table 2).

The effectiveness of the treatment method, the ease of installation, and accessibility of the reactor materials makes this technology an attractive option when binding of free phosphate in surface waters is required. However, the lack of control of the bound iron-phosphate complex may present a significant issue. During this work it was difficult to accurately model the system due to the constantly changing surface of the iron. While this provides a fresh reactive surface upon which the phosphate can bind, it does not retain the iron on the surface, and therefore, binding capacity is 
never reached. The free flowing iron-phosphate complex can then be redeposited into the water body. A better alternative may be a form of iron that is not as readily degraded, and therefore, it can be regenerated similar to an ion exchange resin.

Figure 11. Concentration of phosphate removed over time as measured by the bulk pond water (in) and the reactor effluent (out), and as a ratio of treated/bulk (C/Co).

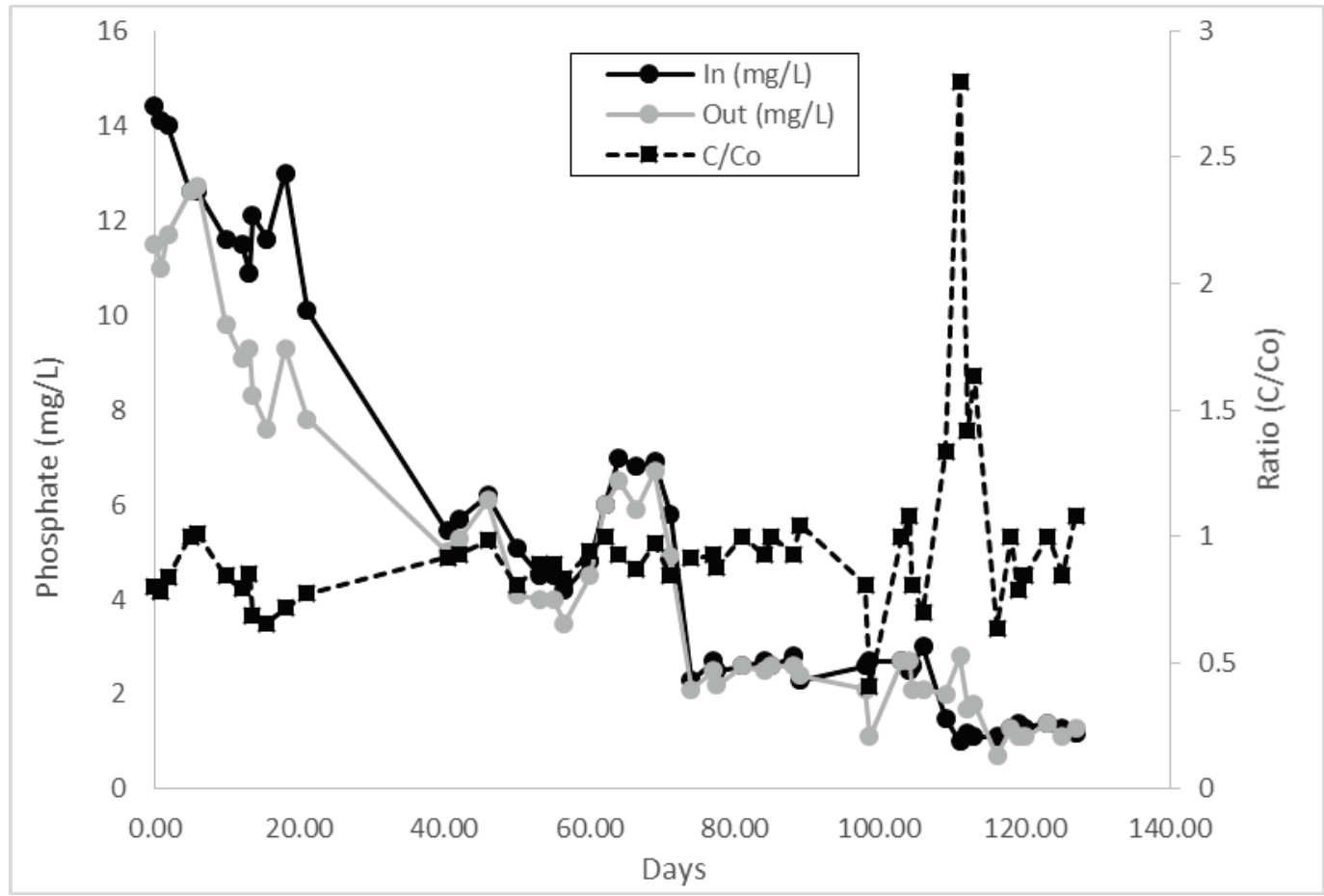


Figure 12. Cumulative phosphate removed from the holding pond over four months.

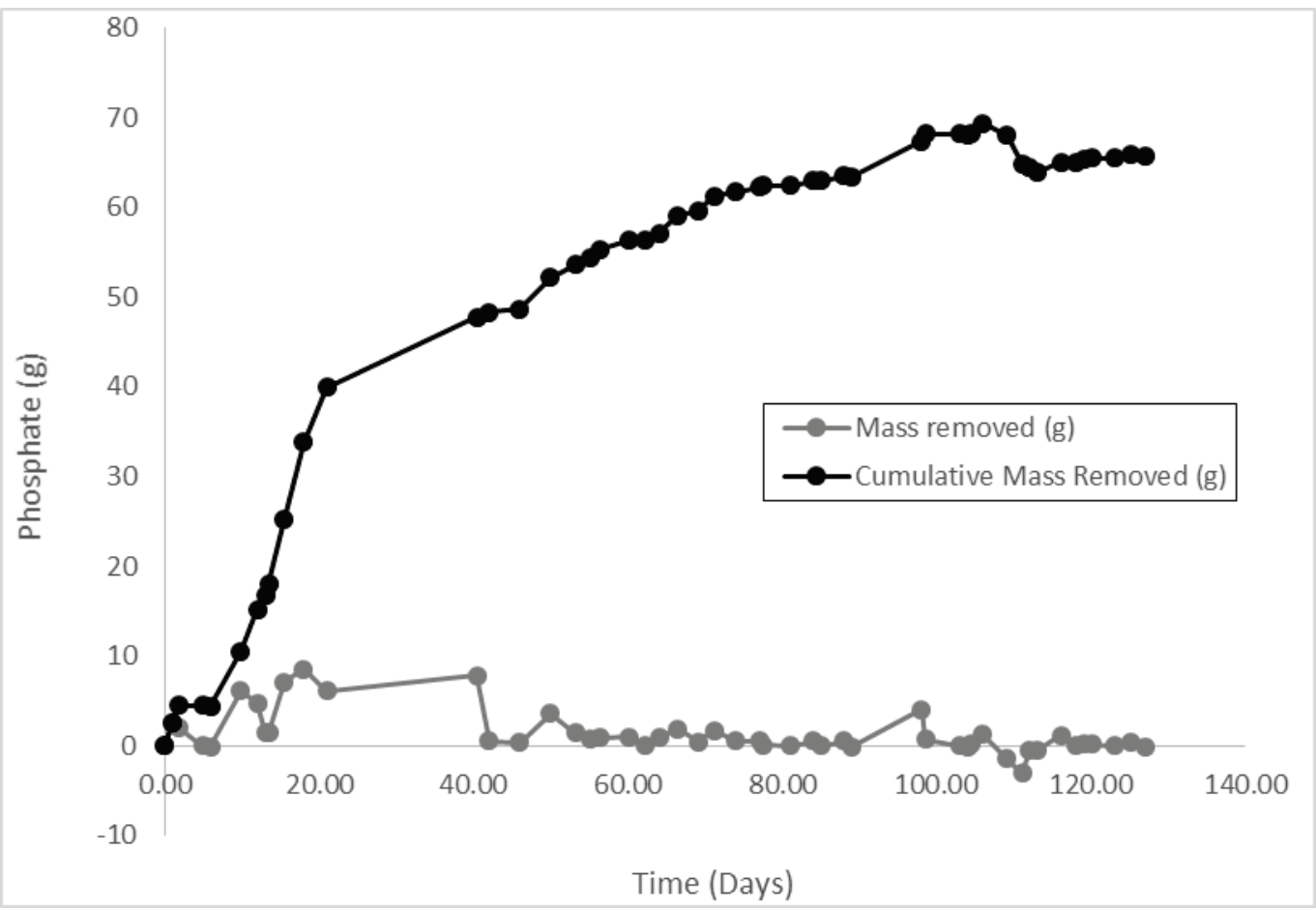




\section{Conclusion}

This study describes a simple, alternative method for removing phosphate from water in a flow through configuration. The phosphate iron binding experiments started at batch bench scale and continued with a meso-scale continuous flow reactor. The study evaluated iron powder, iron filings, and iron plates, and found minimal differences in their abilities to effectively bind the phosphate (Table 2). Treatment levels can be increased with higher contact times through either flow rate reduction or iron mass increase. The reactor is easily constructed and maintained, however, further study is required to focus on downstream removal of the excess iron from solution.

Table 2. Reaction rate summary.

\begin{tabular}{|l|l|l|l|l|l|}
\hline Condition & Order* & $\begin{array}{l}\text { Reaction } \\
\text { Rate }\end{array}$ & Units & Plates & $\mathbf{R}^{2}$ \\
\hline Filings & 2 & 0.006 & $\mathrm{mg} / \mathrm{L} / \mathrm{h}$ & & 0.86 \\
\hline Filings w/o $145 \mathrm{~h}$ & 2 & 0.012 & $\mathrm{mg} / \mathrm{L} / \mathrm{h}$ & & 0.99 \\
\hline Powder & 2 & 0.008 & $\mathrm{mg} / \mathrm{L} / \mathrm{h}$ & & 0.97 \\
\hline Powder w/o $145 \mathrm{~h}$ & 2 & 0.013 & $\mathrm{mg} / \mathrm{L} / \mathrm{h}$ & & 0.99 \\
\hline Iron Plate Recirculate & 0 & 0.057 & $\mathrm{mg} / \mathrm{L} / \mathrm{h}$ & 10 plates & 0.96 \\
\hline Pond & 1 & 0.100 & per day & $10-20$ plates & 0.91 \\
\hline
\end{tabular}




\section{References}

Al-Asheh, S., F. Banat, R. Al-Omari, and Z. Duvnjak. 200o. Predictions of binary sorption isotherms for the sorption of heavy metals by pine bark using single isotherm data. Chemosphere. 41(5):659-665. https://doi.org/10.1016/S0045-6535(99)00497-X.

Barber, T. 2002. Phosphate adsorption by mixed and reduced iron phases in static and dynamic systems. Master of Science. Stanford, CA: Stanford University.

Chislock, M. F., E. Doster, R. A. Zitomer, and A. E. Wilson. 2013. Eutrophication: causes, consequences, and controls in aquatic ecosystems. Nature Education Knowledge 4(4):10.

Diaz, R., and R. Rosenberg. 2008. Spreading dead zones and consequences for marine ecosystems. Science. 321(5891):926-929.

Fredrickson, J. K., and Y. A. Gorby. 1996. Environmental processes mediated by ironreducing bacteria. Current Opinion in Biotechnology 7(3):287-294. https://doi.org/10.1016/S0958-1669(96)80032-2.

Hussain, A., A. Ghafoor, M. Anwar-ul-Haq, and M. Nawaz. 2003. Application of the Langmuir and Freundlich equations for $\mathrm{P}$ adsorption phenomenon in salinesodic soils. International Journal of Agriculture and Biology 5(3):349-356.

Keum, Y.-S., and Q. X. Li. 2004. Reduction of nitroaromatic pesticides with zero-valent iron. Chemosphere. 54:255-263.

Kim, H. G. 2012. HAB mitigation strategies in Korea and eco-friendly new initiatives. In Proceedings $15^{\text {th }}$ International Conference on Harmful Algae (ICHA) 29:219222.

Kortsee, G. J. J., K. J. Appledoorn, C. F. C. Bonting, E. W. J. vanNiel, and H. W. vanVeen. 1994. Biology of phosphate-accumulating bacteria involved in enhanced biological phosphorous removal. FEMS Microbiology Reviews 15(2-3):137-153. https://doi.org/10.1111/j.1574-6976.1994.tboo131.x.

Kudela, R. M., E. Berdalet, S. Bernard, M. Burford, L. Fernand, S. Lu, S. Roy, P. Tester, G. Usup, R. Magnien, D.M. Anderson, A. Cembella, M. Chinain, G. Hallegraeff, B. Reguera, A. Zingone, H. Enevoldsen, and E. Urban. 2015. Harmful algal blooms: A scientific summary for policy makers. Paris, France: IOC/UNESCO.

Lijklema, L. 1980. Interaction of orthophosphate with iron (III) and aluminum hydroxides. Environmental Science and Technology 14:537-541.

Liu, C., and P. M. Huang. 2000. Kinetics of phosphate adsorption on iron oxides formed under the influence of citrate. Canadian Journal of Soil Science 80:445-454. https://doi.org/10.4141/S99-079.

Mao, Y., and Q. Yue. 2016. Kinetic modeling of phosphate adsorption by preformed and in situ formed hydrous ferric oxides at circumneutral pH. Scientific Reports 6:35292. 
Metcalf, E., and H. Eddy. 1991. Wastewater engineering: treatment, disposal, and reuse. New York, New York: McGraw Hill.

Mezenner, N. Y., and A. Bensmaili. 2009. Kinetics and thermodynamic study of phosphate adsorption on iron hydroxide-eggshell waste. Chemical Engineering Journal 147:87-96.

Mur, L. E., O. M. Skulberg, and H. Utkilen. 1999. Toxic cyanobacteria in water: A guide to their public health consequences, monitoring, and management. In Cyanobacteria in the Environment. I. Chorus and J. Bartram, editors. World Health Organization (WHO).

National Science and Technology Council. 2016. Harmful algal blooms and hypoxia comprehensive research plan and action strategy: an interagency report. Vol. Feb, 11 2016. Washington, DC: National Science and Technology Council Subcommittee on Ocean Science and Technology.

Rich, D. 2005. The removal of total phosphorous from natural waters by precipitation. In Environmental Science 121.

Sindelar, H. R., J. N. Yap, T. H. Boyer, and M. T. Brown. 2015. Algae scrubbers for phosphorus removal in impaired waters. Ecological Engineering 85:144-158. https://doi.org/10.1016/i.ecoleng.2015.09.002.

Son, A., J. Lee, P. C. Chiu, B. J. Kim, and D. K. Cha. 2006. Microbial reduction of perchlorate with zero-valent iron. Water Research 40(10):2027-2032. https://doi.org/10.1016/j.watres.2006.03.027.

Spiteri, C., P. Van Cappellen, and P. Regnier. 2008. Surface complexation effects on phosphate adsorption to ferric iron oxyhydroxides along $\mathrm{pH}$ and salinity gradients in estuaries and coastal aquifers. Geochimica et Cosmochimica Acta. 72(14):3431-3445. https://doi.org/10.1016/i.gca.2008.05.003.

Wang, Z., E. Nie, J. Li, M. Yang, Y. Zhao, X. Luo, and Z. Zheng. 2012. Equilibrium and kinetics of adsorption of phosphate onto iron-doped activated carbon. Environmental Science and Pollution Research 19(7):2908-2917. 


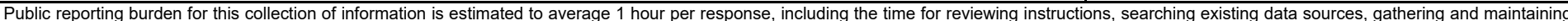

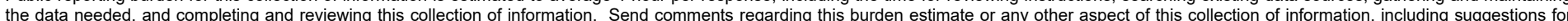

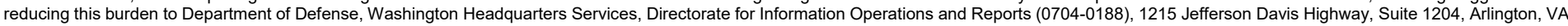

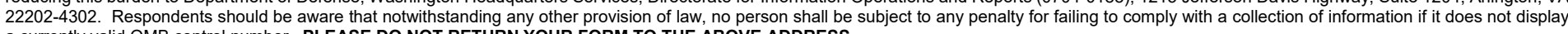
a currently valid OMB control number. PLEASE DO NOT RETURN YOUR FORM TO THE ABOVE ADDRESS.
1. REPORT DATE (DD-MM-YYYY) 2. REPORT TYPE
October 2018 Final report

3. DATES COVERED (From - To)

\section{TITLE AND SUBTITLE}

Abiotic Removal of Phosphate From Surface Water - Bench Scale to Meso-Scale

5a. CONTRACT NUMBER

5b. GRANT NUMBER

5c. PROGRAM ELEMENT NUMBER

\section{AUTHOR(S)}

Carina M. Jung, Jed O. Eberly, G. Alon Blakeney, and Heather M. Knotek-Smith

\section{5d. PROJECT NUMBER} 454747

5e. TASK NUMBER

5f. WORK UNIT NUMBER

20D296

7. PERFORMING ORGANIZATION NAME(S) AND ADDRESS(ES)

8. PERFORMING ORGANIZATION REPORT NUMBER

U.S. Army Engineer Research and Development Center, Environmental Laboratory 3909 Halls Ferry Road, Vicksburg, MS 39180-6199

ERDC/EL TR-18-12

\section{SPONSORING / MONITORING AGENCY NAME(S) AND ADDRESS(ES)}

10. SPONSOR/MONITOR'S ACRONYM(S)

Headquarters, U.S. Army Corps of Engineers

Washington, DC 20314-1000

\section{SPONSOR/MONITOR'S REPORT} NUMBER(S)

\section{DISTRIBUTION / AVAILABILITY STATEMENT}

Approved for public release; distribution unlimited.

\section{SUPPLEMENTARY NOTES}

\section{ABSTRACT}

Cultural eutrophication is a primary cause of impairment to recreational and commercially important waterways. Nutrient loading of waterways through release of fertilizers and sewage, among other substrates high in growth-limiting substrates (phosphorus, nitrogen, and carbon) allows for unchecked growth of photosynthesizers such as blue-green algae (cyanobacteria). Significant cyanobacterial growth may result in plant die-off, hypoxia, or anoxia, and the proliferation of harmful algal blooms (HABs). Methods exist to bind and inactivate nutrients like phosphorous but these do not remove nutrients from the waterway. This report presents a passive method for physical removal of phosphate $\left(\mathrm{PO}_{4}\right)$ by moving water over reduced iron plates, yielding an iron oxide-phosphate complex that can be passively filtered with sand and activated carbon. Both lab- and field-scale reactors were tested and compared for phosphate removal rates and performance was evaluated for treating a small contained pond with high phosphate. The reactor configuration presented herein removed phosphate from the experimental pond at a rate of $0.1004 \mathrm{mg} \mathrm{PO} / \mathrm{L} /$ day. The effectiveness of the treatment method, the ease of installation, low cost, and accessibility of the reactor materials makes this technology an attractive option when binding of free phosphate in surface waters is required.

\begin{tabular}{|c|c|c|c|c|c|}
\hline \multicolumn{2}{|c|}{$\begin{array}{l}\text { 15. SUBJECT TERMS } \\
\text { Nutrient pollution of water } \\
\text { Waterways }\end{array}$} & $\begin{array}{l}\text { Rivers } \\
\text { Eutrophication }\end{array}$ & \multicolumn{3}{|c|}{$\begin{array}{l}\text { Algal blooms } \\
\text { Water quality } \\
\text { Water--Purification }\end{array}$} \\
\hline \multicolumn{3}{|c|}{ 16. SECURITY CLASSIFICATION OF: } & $\begin{array}{l}\text { 17. LIMITATION } \\
\text { OF ABSTRACT }\end{array}$ & $\begin{array}{l}\text { 18. NUMBER } \\
\text { OF PAGES }\end{array}$ & $\begin{array}{l}\text { 19a. NAME OF RESPONSIBLE } \\
\text { PERSON }\end{array}$ \\
\hline $\begin{array}{l}\text { a. REPORT } \\
\text { UNCLASSIFIED }\end{array}$ & $\begin{array}{l}\text { b. ABSTRACT } \\
\text { UNCLASSIFIED }\end{array}$ & $\begin{array}{l}\text { c. THIS PAGE } \\
\text { UNCLASSIFIED }\end{array}$ & & 32 & $\begin{array}{l}\text { 19b. TELEPHONE NUMBER (include } \\
\text { area code) }\end{array}$ \\
\hline
\end{tabular}

